\title{
Development of the seminiferous tubules after neonatal hemicastration in the boar*
}

\author{
M. S. Kosco, K. J. Loseth and B. G. Crabo \\ Department of Animal Science, University of Minnesota, St Paul, Minnesota 55108, USA
}

\begin{abstract}
Summary. Development of the prepubertal seminiferous tubules of the right testis was characterized morphometrically every 14 days from 10 to 122 days of age in intact boars (I) and boars hemicastrated (HC) on Day 10 of life from two herds (Trial 1 and Trial 2). Comparisons were made between the remaining testis of Group HC boars and one testis in Group I boars. By 38 days of age seminiferous tubule length in Group HC boars was double $(P<0.0001)$ that in Group I boars. Seminiferous tubule length did not differ between trials within treatments. The diameter of the seminiferous tubule was similar in Group HC and I boars but was greater $(P<0.05)$ in Trial-1 than Trial-2 boars from Day 80 to 122 of life. Relative mass (mass of tissue/body mass) of Sertoli cells became 2-fold greater $(P<0.0001)$, in Group HC than in one testis of Group I boars by 38 days of age and this difference was maintained throughout the experimental period. The relative mass of Sertoli cells was greater $(P<0.05)$ in Trial-1 than Trial-2 boars within each treatment between 80 and 122 days of age. The relative mass of gonocytes was similar for all groups and treatments of boars. By 122 days of age the relative mass of spermatogenic cells was greater $(P<0.05)$ in Group HC than in one testis of Group I boars and greater $(P<0.01)$ in Trial-1 than Trial-2 boars within each treatment. Onset of spermatogenesis was first observed at 80 and 94 days of age in boars in Groups $\mathrm{HC}$ and I, respectively. Development of seminiferous tubule lumen was first observed at 94 and 108 days of age in boars in Groups HC and I respectively. Seminiferous tubule lumen, taken as a measure of fluid secretion of the Sertoli cells, occupied a greater $(P<0.01)$ portion of seminiferous tubule in Trial- 1 than Trial-2 boars within each treatment at the end of the experimental period. It is concluded that neonatal hemicastration of boars rapidly caused a compensatory seminiferous tubule elongation apparently due to Sertoli cell proliferation and an earlier onset of spermatogenesis. However, the gonocytes do not proliferate until they transform into spermatogonia.
\end{abstract}

Keywords: boar; testis; hemicastration; seminiferous tubule; spermatogenesis

\section{Introduction}

Compensatory development of the remaining gonad after hemicastration occurs in the male rabbit, rat, ram, bull, boar and stallion (Lipschütz, 1922; Land \& Carr, 1975; Cunningham et al., 1978; Barnes et al., 1980a; Sundby et al., 1981; Ott et al., 1984; Putra \& Blackshaw, 1985). Neonatal hemicastration of bulls results in increased sperm production per testis (Barnes et al., 1980b) and that of rams in increased epididymal sperm reserves (Voglmayer \& Mattner, 1968), suggesting that neonatal hemicastration may be used as a model for studying factors involved in prepubertal development of the seminiferous tubule and its relationship to spermatogenesis. Hemicastration of boars at 10 days of age

\footnotetext{
*Reprint requests to Professor B. G. Crabo.
} 
results in compensatory doubling of the mass of the remaining gonad which is completed in fewer than 28 days and coincides with elevations in plasma FSH and GH concentrations (Kosco et al., 1987). The objective of this paper is to describe the morphology of prepubertal development of the seminiferous tubule and spermatogenesis after neonatal hemicastration in the same boars for which endocrine data have been presented previously (Kosco et al., 1987).

\section{Materials and Methods}

Animals. Forty-eight crossbred (Landrace $\times$ Duroc $\times$ Yorkshire) boars, farrowed in January on a University of Minnesota farm, were randomly divided into two equal groups. One group was hemicastrated by removal of the left testis at 10 days of age (Group HC), and the other group was left intact (Group I). This experiment was replicated with 48 crossbred (Duroc $\times$ Yorkshire $\times$ Hampshire) boars farrowed in June on another University of Minnesota farm. As previously reported (Kosco et al., 1987), the boars farrowed in June exhibited delayed onset of the pubertal testicular growth phase in comparison to those farrowed in January. Therefore, in this study the two groups of boars were denoted as Trial 1 (farrowed in January) and Trial 2 (farrowed in June). The boars were kept and castrated as described previously (Kosco et al., 1987).

Six boars from each treatment were at the time of hemicastration randomly assigned to have the right testis removed for histological examination every 14 days from 24 to 122 days of age. At the time of surgery, each boar was weighed and then administered $2.2 \mathrm{mg}$ xylazine $/ \mathrm{kg}$ intramuscularly followed by pentabarbitone sodium administered symptomatically via jugular venepuncture. Vascular fixation was performed using a bichambered perfusion pump containing Ringer's $\left(0.147 \mathrm{M}-\mathrm{NaCl}, 0.004 \mathrm{M}-\mathrm{KCl}\right.$ and $\left.0.003 \mathrm{M}-\mathrm{CaCl}_{2}\right)$ and glutaraldehyde $(4 \%$ glutaraldehyde in $0.2 \mathrm{M}$-s-collidine $\mathrm{pH} 7.3$ at $22^{\circ} \mathrm{C}$ ) solutions. Pump valving was constructed to allow Ringer's and glutaraldehyde solutions to flow separately through a perfusion needle connected to the pump via polyethylene tubing under $180 \mathrm{mmHg}$ pressure. Needles ranging in size from 21- to 27 -gauge were chosen to fit the size of the testicular artery. Upon exteriorization of the right testis, the needle was inserted into the testicular artery. When the movement of blood into the polyethylene tubing was observed, the spermatic cord was clamped anterior to the pampiniform plexus and cut immediately. The testis was first perfused with Ringer's solution via the testicular artery to remove blood retained by the testis, then with glutaraldehyde solution until the testis became hard and yellow. The total volume of glutaraldehyde solution used was approximately twice the estimated testicular weight. The fixed testis was then trimmed of extraneous material and weighed.

Tissue preparation. Testes fixed by perfusion were cut transversely midway between the testicular poles, and $1 \mathrm{~mm}^{3}$ tissue blocks were removed from apparently adequately fixed areas of parenchyma. Tissue blocks were then placed in glass scintillation vials containing ice-cold glutaraldehyde fixative for approximately 7 days. They were then rinsed in ice-cold $s$-collindine $(0.2 \mathrm{M}, \mathrm{pH} 7.3)$, post-fixed in $1 \%$ osmium tetroxide for $1.5 \mathrm{~h}$ and dehydrated in ascending grades $(50-95 \%)$ of ethanol at $5{ }^{\circ} \mathrm{C}$. The blocks in $95 \%$ ethanol were allowed to warm to room temperature, rinsed in absolute ethanol at 15 -min intervals for $1 \mathrm{~h}$ and then in 3 changes of propylene oxide at $1 \cdot 5-\mathrm{min}$ intervals. They were immersed next in a 1:1 mixture of propylene oxide and Poly/Bed 812 Embedding Medium (Polyscience, Warrington, PA) for $8 \mathrm{~h}$, then in Poly/Bed 812 for $12 \mathrm{~h}$. Five randomly selected tissue blocks per testis were individually placed in BEEM capsules (size 000) containing fresh Poly $/$ Bed and polymerized at $65^{\circ} \mathrm{C}$ for $24 \mathrm{~h}$.

Sections $1 \mu \mathrm{m}$ in thickness were cut using glass knives on an LKB 8800 Ultrotome III and stained with $1 \%$ toluidine blue 0 in $25 \%$ sodium carbonate (Trump et al., 1961) over a cool flame of a Bunsen burner (Björkman, 1962) for $1 \mathrm{~min}$ and then rinsed in distilled water. Sections were allowed to air dry for $24 \mathrm{~h}$ before permanent mounting.

Morphometric analysis. One section from each of the 5 randomly selected tissue pieces was photographed on a Zeiss Photomicroscope II using the $\times 10$ objective and Kodak FX135 panatomic black and white film so that virtually the whole section appeared on the film. Photographs of a $2-\mathrm{mm}$ stage micrometer (divided into $0.01 \mathrm{~mm}$ units) were taken on each film to allow a standardization of magnification $(\times 473)$ for each print. Morphometric analysis was performed using a 228-point $(\mathrm{z}=1.5 \mathrm{~cm})$ Weibel grid (Weibel, 1979) which was superimposed on each section. Volume densities $\left(V_{v}\right)$ of testicular components were determined using the formula

$$
\mathrm{V}_{\mathrm{v}}=\mathrm{P}_{\mathrm{c}} / \mathbf{P}_{\mathrm{t}}
$$

where $P_{c}$ was the number of points superimposed over a particular testicular component and $P_{1}$ the total number of points in the reference area. Volume densities for the following seminiferous tubule structures were determined: Sertoli cells, cytoplasm and nuclei of gonocytes, spermatogonia, spermatocytes, spermatids, tubule lumen and basement membrane. Sertoli nuclei were not detectable on all prints and therefore not determined. Gonocytes and spermatogenetic cells appeared clearly on the prints. Sertoli cells were identified as tubular cells not characterized as any of the other structures mentioned. This probably caused an underestimation of Sertoli cell mass in tubules featuring spermatogenesis since Sertoli cell bridges between spermatogenic cells were undetectable with light microscopy. No correction factors for tissue preparation were used since all tissues were prepared and handled the same way and no shrinkage or collapsed vessels could be detected microscopically in any section.

The assumption was made that all testicular components had a density of one. Testicular and parenchymal volume, volume density of parenchyma, mass of parenchyma, mass of seminiferous tubule components and mass 
ratio of parenchyma and seminiferous tubule components in relation to body mass (relative mass) were determined for each perfusion-fixed right testis. Testicular and parenchymal volume per testis were determined using a sphere as a model in which testicular and parenchymal radii were determined from photographs taken from transverse sections obtained midway between the testicular poles. The parenchymal volume density per testis was determined by dividing the parenchymal volume by the testicular volume. Mass of parenchyma for each testis was determined by multiplying the parenchymal volume density by the testicular mass. Mass of seminiferous tubule components per testis was determined by multiplying the volume density of the components by the parenchymal mass. The relative mass of the parenchyma and seminiferous tubule components for each testis was determined by dividing the mass of the parenchyma and seminiferous tubule component by the body mass.

Diameter and total length of the seminiferous tubule were determined for each perfusion-fixed right testis. Diameter of the seminiferous tubule for each testis was determined from measurements of the least diameter of rounded seminiferous tubule cross-sections on the photomicrographs at $\times 473$, using 15 separate measurements per boar. Using the cylinder as a model, total length of the seminiferous tubule of each testis was calculated by dividing the mass by the surface area.

Since the parenchyma and seminiferous tubule components may or may not develop at a rate equal to the rate of body growth in boars, masses are expressed as relative mass to emphasize growth in relation to the animal as well as marked changes in growth rate.

Statistical analysis. Results were analysed using SAS (Statistical Analysis System, 1982) as a completely random design in a factorial arrangement. All values were analysed for treatment, age and trial, as well as for interactions between the variables. No significant treatment- $x$-trial interaction occurred for any parameter. Treatment- $x$-age and age- $x$-trial interactions were observed, and were apparently due to a later onset of pubertal weight increase in Trial- 2 boars. Therefore, Trial-1 and Trial-2 results are represented separately wherever a significant interaction occurred, although interactions never involved the hemicastration effect. When significant differences occurred $(P \leqslant 0.05)$ means were separated using Duncan's Multiple Range test.

\section{Results}

\section{Response of the parenchymal mass}

Growth of the body and testes in these boars has previously been reported (Kosco et al., 1987). The relative mass of the parenchyma (Fig. 1a) of Group-I boars remained essentially unchanged from 10 to 80 days of age. From 80 to 122 days of age there was a greater $(P<0.05)$ increase in relative mass of the parenchyma in Trial-1 and Trial-2 Group-I boars. By 38 days of age the increase in relative mass of the parenchyma in Group-HC boars was double $(P<0.0001)$ that in Group-I boars. This difference was maintained throughout the remainder of the study. From 38 to 80 days of age relative mass of the parenchyma of Group-HC boars remained essentially unchanged. From 80 to 122 days of age there was a greater increase $(P<0.05)$ for Trial-1 than for Trial-2 Group-HC boars.

Percentage of the testes occupied by parenchyma was related to the stage of testicular growth and not to treatment or trial within a treatment. The parenchyma comprised $82 \%$ of the testicular mass at 10 days of age and increased $(P<0.05)$ to $95 \%$ by 122 days of age. Testes weighing over $14 \mathrm{~g}$ consistently contained $>90 \%$ parenchyma.

\section{Response of the mass, length and diameter of the seminiferous tubule}

The percentage of the parenchymal mass comprised by the seminiferous tubules was related to the stage of parenchymal development and not to treatment or trial within a treatment. Seminiferous tubules comprised $20 \%$ of the parenchymal mass at 10 days of age and increased $(P<0.05)$ to $51 \%$ of the parenchymal mass by 80 days of age. In boars exhibiting an increase in the relative mass of the parenchyma from 80 to 122 days of age (Trial-1 Group-I and -HC boars and Trial-2 Group-HC boars), the portion of the parenchymal mass comprised by the seminiferous tubules also increased $(P<0.05)$ from $51 \%$ to $74 \%$. In Trial-2 Group-I boars, in which no increase in relative mass of the parenchyma was noted from 80 to 122 days of age, the portion of the parenchymal mass comprised by the seminiferous tubules remained at $\sim 50 \%$. 
(a) Parenchyma
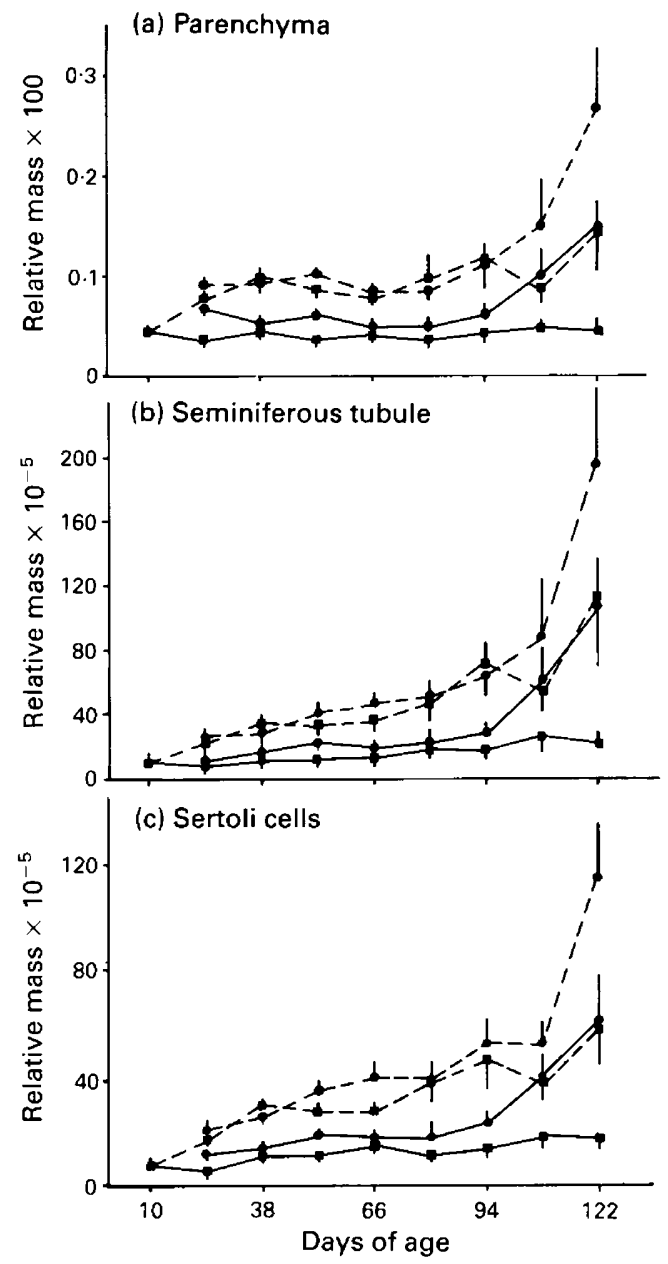

Fig. 1. Relative mass (component mass/body mass) of the parenchyma (a), and seminiferous tubule (b) and Sertoli cells (c) every 14 days from 10 to 122 days of age for Trial-1 ( $)$ and Trial-2 ( $\mathbf{\square})$ intact boars $(-)$ and boars hemicastrated on Day $10(---)$. All values mean \pm s.e. The increase in relative mass of the parenchyma from 80 to 122 days of age was $207 \%(P<0.05)$ for Trial-1 Group-I boars, 202\% $(P<0.05)$ for Trial-1 Group-HC boars and $49 \%(P<0.05)$ for Trial-2 Group-HC boars. The increase in relative mass of the seminiferous tubule from 80 to 122 days of age was $436 \%(P<0.05)$ for Trial-1 Group-I boars, $292 \%$ $(P<0.06)$ for Trial-1 Group-HC boars and $117 \%(P<0.05)$ for Trial-2 Group-HC boars. The increase in relative mass of Sertoli cells from 80 to 122 days of age was $297 \%(P<0.05)$ for Trial-1 Group-I boars, $608 \%(P<0.05)$ for Trial-1 Group-HC boars and $273 \%(P<0.05)$ for Trial-2 Group-HC boars.

The relative mass of the seminiferous tubule (Fig. 1b) of Group-I boars remained essentially unchanged from 10 to 80 days of age. From 80 to 122 days of age there was a greater $(P<0.01)$ increase in relative mass of the seminiferous tubule for Trial-1 than for Trial-2 Group-I boars. Neonatal hemicastration of boars at 10 days of age resulted in a $117 \%$ increase $(P<0.0001)$ in the relative mass of the tubule by 38 days of age, when compared to Group-I boars, and this difference was maintained for the duration of the study. From 38 to 80 days of age, the relative mass of the seminiferous tubule of Group-HC boars remained essentially unchanged. From 80 to 122 days of age there was a greater increase $(P<0.01)$ in relative mass for Trial-1 than for Trial-2 Group-HC boars. 
Diameter of the seminiferous tubule was not affected by hemicastration. The diameter increased $(P<0.05)$ from $61 \mu \mathrm{m}$ in 10 -day-old boars to $74 \mu \mathrm{m}$ in 80 -day-old boars. From 80 to 122 days of age the increase in diameter was greater $(P<0.05)$ for Trial- 1 than for Trial-2 boars (Fig. $2 \mathrm{~b})$.

Total length of the seminiferous tubule (Fig. 2a) in Group-I boars increased $(P<0.0001)$ linearly from $92 \mathrm{~m}$ in 10-day-old boars to $2173 \mathrm{~m}$ in 122-day-old boars. Hemicastration of boars at 10 days of age resulted in a doubling $(P<0.001)$ of tubule length over that of Group-I boars, evident as early as 28 days after hemicastration. This difference was maintained during the remainder of the study. The length of the seminiferous tubule was similar for Trial-1 and Trial- 2 boars within each treatment.

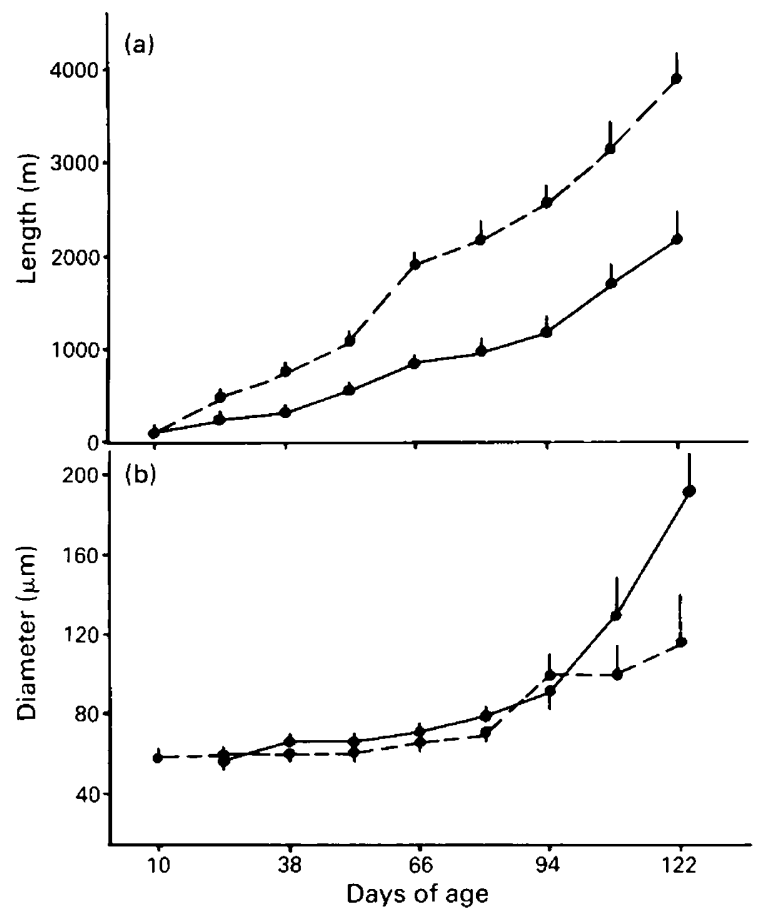

Fig. 2. Total seminiferous tubule length (a) every 14 days from 10 to 122 days of age for intact boars $(-)$ and boars hemicastrated on Day $10(--)$ and seminiferous tubule diameter (b) every 14 days from 10 to 122 days of age for Trial-1 (-) and Trial-2 (-- ) boars. All values mean \pm s.e. The increase in seminiferous tubule diameter from 80 to 122 days of age was $141 \%(P<0.05)$ for Trial-1 boars and $61 \%(P<0.05)$ for Trial-2 boars.

\section{Response of the cellular elements of the seminiferous tubule}

The relative mass of Sertoli cells (Fig. 1c) in Group-I boars remained essentially unchanged from 10 to 80 days of age. From 80 to 122 days of age the increase in the relative mass of Sertoli cells was greater $(P<0.001)$ in Trial-1 than in Trial-2 Group-I boars. Neonatal hemicastration of boars at 10 days of age resulted in a doubling $(P<0.0001)$ of the relative mass of Sertoli cells when compared to a single testis of Group-I boars by 38 days of age, and this difference was maintained for the length of the study. From 80 to 122 days of age the increase in the relative mass of Sertoli cells was greater $(P<0.001)$ in Trial-1 than in Trial-2 Group-HC boars.

Relative mass of gonocytes (Fig. 3a), gonocyte cytoplasm and gonocyte nuclei (Fig. 3b) was similar for all groups of boars. The relative mass of gonocytes increased $(P<0.05)$ from 10 to 80 days of age 
and thereafter decreased $(P<0.001)$ due to the transformation of gonocytes into spermatogonia. The relative mass of gonocyte cytoplasm doubled $(P<0.0001)$ from 10 to 80 days of age. The relative mass of gonocyte nuclei remained essentially unchanged from 10 to 80 days of age.

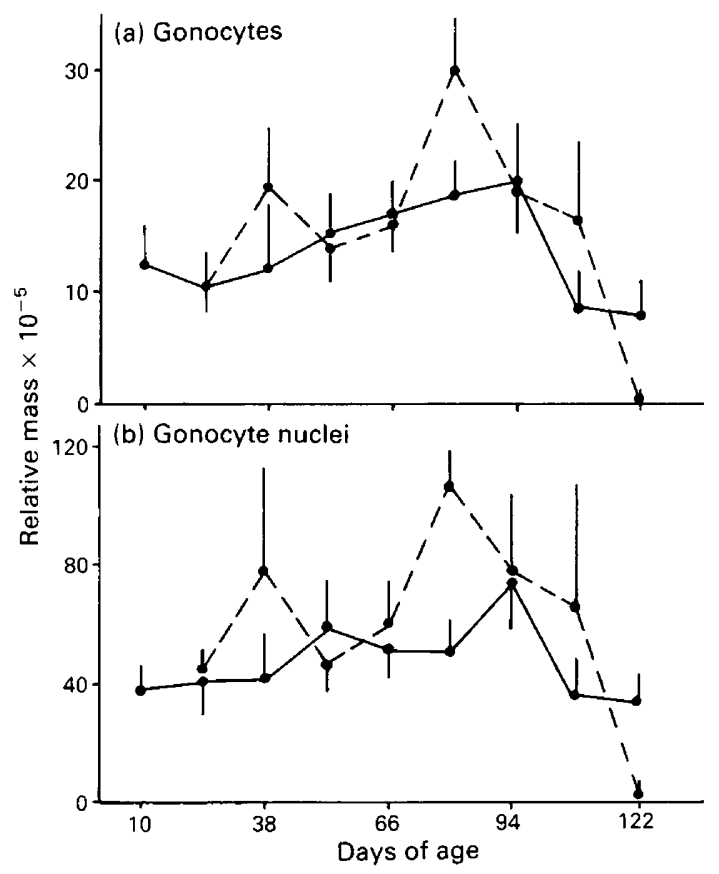

Fig. 3. Relative mass (component mass/body mass) of gonocytes (a) and gonocyte nuclei (b) every 14 days from 10 to 122 days of age for intact boars (-) and boars hemicastrated on Day $10(---)$. All values mean \pm s.e. The relative mass of gonocytes increased by $90 \%$ $(P<0.05)$ from 10 to 80 days of age and decreased by $84 \%(P<0.0001)$ from 80 to 122 days of age.

The greater $(P<0.05)$ relative mass of spermatogenic cells (spermatocytes and spermatids) observed in Group-HC than in Group-I boars at 122 days of age was due to earlier onset of spermatogenesis in Group-HC boars than in Group-I boars, at 80 days and 94 days of age, respectively (Figs 4, 5f). The relative mass of spermatogenic cells was also greater $(P<0.01)$ for Trial-1 than Trial-2 boars within each treatment (Fig. 4). At 122 days of age spermatogenesis had not begun in any of the Trial-2 Group-I boars, whereas Trial-1 Group-I boars had considerable numbers of spermatogonia and primary spermatocytes (Figs 6a, 6c). In Trial-1 Group-HC boars there were considerable numbers of spermatogonia, primary spermatocytes and spermatids (round and elongated), whereas in Trial-2 Group-HC boars there were spermatogonia and primary spermatocytes but no spermatids (Figs 6b, 6d).

Development of the seminiferous tubule lumen was taken as a measure of onset of Sertoli cell secretion and was first observed in Group-HC boars at 94 days of age as compared to 108 days of age for Group-I boars. By 122 days of age Group-HC boars had a greater $(P<0.01)$ relative mass of seminiferous tubule lumen than did Group-I boars. There was also a difference $(P<0.05)$ between trials of boars within each treatment. Seminiferous tubule luminal development, although not evident in Trial-2 Group-I boars, was present in Trial-1 Group-I boars by 108 days of age, and it was $76 \%$ greater in Trial-1 as compared to Trial-2 Group-HC boars at 122 days of age. 


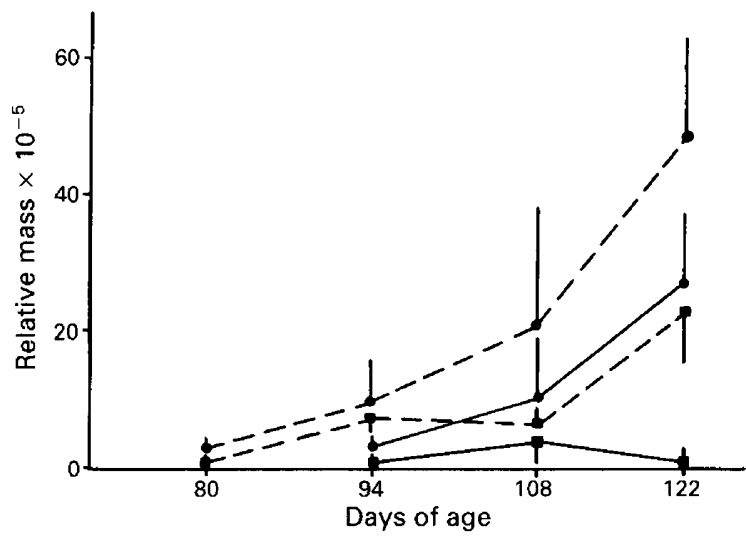

Fig. 4. Relative mass (component mass/body mass) of spermatogenic cells every 14 days from 80 to 122 days of age and 94 to 122 days of age, respectively, for Trial-1 ( $)$ and Trial-2 ( $\boldsymbol{\square})$ intact boars (-) and boars hemicastrated on Day $10(---)$. All values mean \pm s.e. The relative mass of spermatogonial cells at 122 days of age was $83 \%$ greater $(P<0.01)$ for Trial-1 than for Trial-2 Group-HC boars.

\section{Discussion}

The seminiferous tubules comprise $20 \%$ of the parenchymal mass during the first week of life and increase to half of the parenchymal mass by 11 weeks of age. The increase is due to tubular elongation occurring in response to an increase in mitotic activity of Sertoli cells (Erickson $e t$ al., 1963; Tran et al., 1981). From 11 to 17 weeks of age the portion of the parenchymal mass consisting of seminiferous tubules increases from $50 \%$ to $75 \%$ due to an increase in seminiferous tubule diameter in response to an increase in cytoplasmic volume of Sertoli cells and the onset of spermatogenesis (Swierstra, 1976; van Straaten \& Wensing, 1977). Compensatory increases in parenchymal and seminal tubule masses occurring within 28 days of neonatal hemicastration of boars do not influence the percentage of the testis mass comprising parenchyma or the percentage of the parenchymal mass comprising seminiferous tubules, in agreement with observations by Putra \& Blackshaw (1985) in boars hemicastrated at 1-5 months of age.

The technique used in the present investigation did not always allow differentiation between Sertoli cell nuclei and cytoplasm and so Sertoli nuclei mass was not determined. However, since seminiferous tubule diameter did not change, and proliferation of Sertoli cell numbers has been reported previously after hemicastration in boars and several other species (Jenkins \& Waites, 1983; Waites et al., 1983; Orth et al., 1984; Hochereau de Reviers et al., 1984; Putra \& Blackshaw, 1985), the compensatory increase in mass of Sertoli cells observed here is probably due to proliferation of Sertoli cell numbers.

The compensatory development of Sertoli cells observed in Group-HC boars coincides with elevation in plasma growth hormone (GH) and follicle-stimulating hormone (FSH) concentrations (Kosco et al., 1987). Immature Sertoli cells of several species show increased mitotic activity in response to FSH (Courot, 1967; Steinberger \& Steinberger, 1977; Fritz, 1978; Chevalier, 1979; Means et al., 1980) and may be involved in compensatory Sertoli cell proliferation in neonatally hemicastrated rams and rats (Waites et al., 1983; Orth et al., 1984). FSH in Group-HC boars was elevated above values for intact animals only during the last 14 days of compensatory Sertoli cell proliferation, whereas plasma $\mathrm{GH}$ concentration in Group-HC boars was elevated during the entire period of compensatory proliferation of Sertoli cells (Kosco et al., 1987).

Compensatory proliferation of Sertoli cells and elongation of the seminiferous tubule in Group-HC boars occurs during a period of elevated plasma testosterone concentration in the boar 

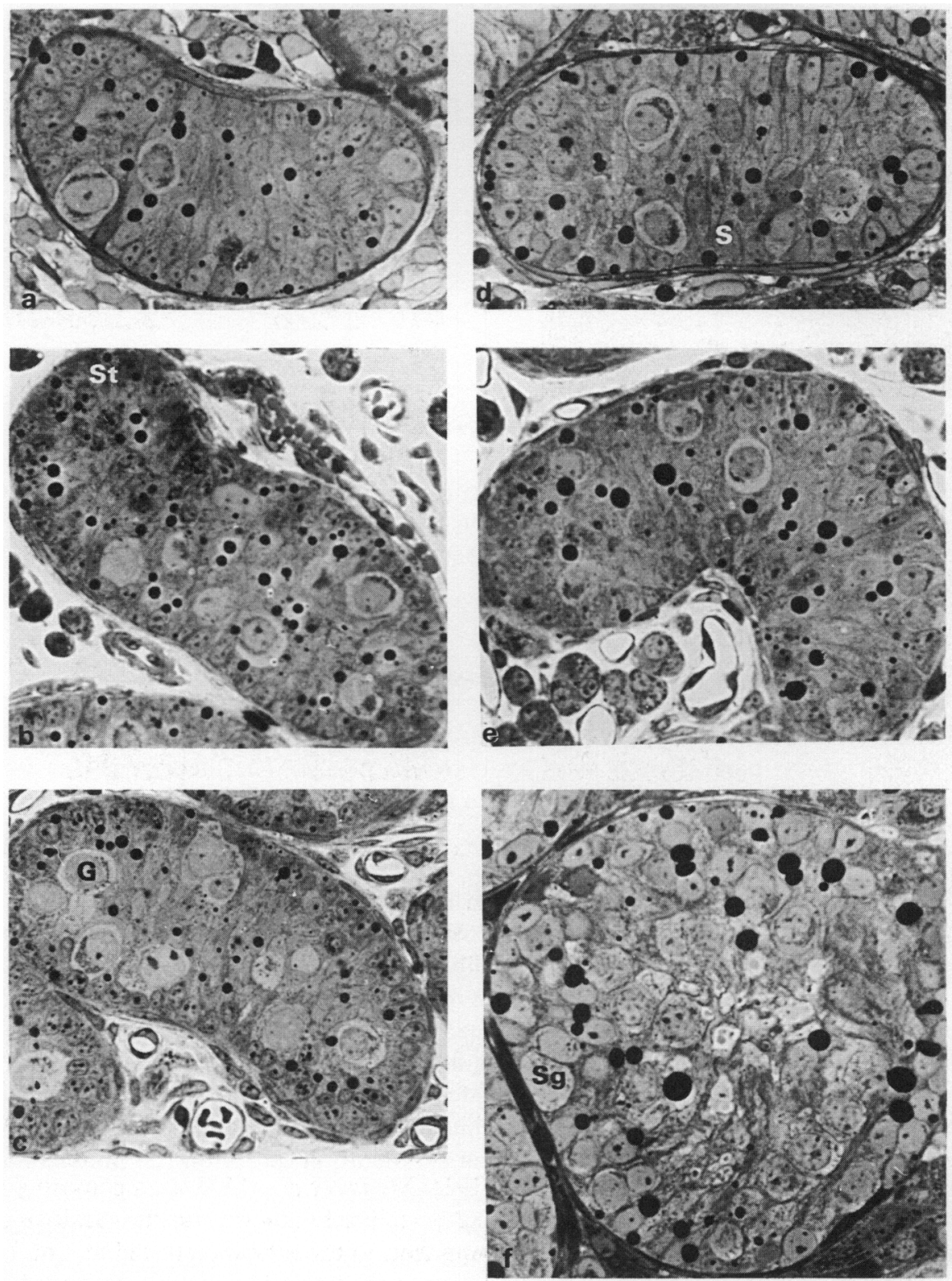

Fig. 5. Light micrographs of seminiferous tubules from intact boars at 24 days (a), 52 days (b) and 80 days (c) of age and from boars hemicastrated on Day 10 at 24 days (d), 52 days (e) and 80 days (f) of age. Gonocytes $(G)$ have a large nucleus and a pale-staining cytoplasm. Gonocyte mitochondria are adjacent to the nucleus. Gonocytes are abundant in all seminiferous tubules (St) and are surrounded by Sertoli cells (S), containing large osmium-staining lipid droplets. Spermatogonia $(\mathrm{Sg})$ are first observed in boars hemicastrated on Day 10 at 80 days of age. Staining $1 \%$ toluidine blue; $\times 400$.

(Colenbrander et al., 1978; Herrera et al., 1983; Kosco et al., 1987). Compensatory testicular growth and proliferation of Sertoli cells in neonatally hemicastrated bulls and rams, respectively, is delayed until there is a significant elevation in plasma testosterone concentration (Boockfor et al., 1983; Jenkins \& Waites, 1983; Waites et al., 1983; Al-Haboby et al., 1984), signifying a relationship 

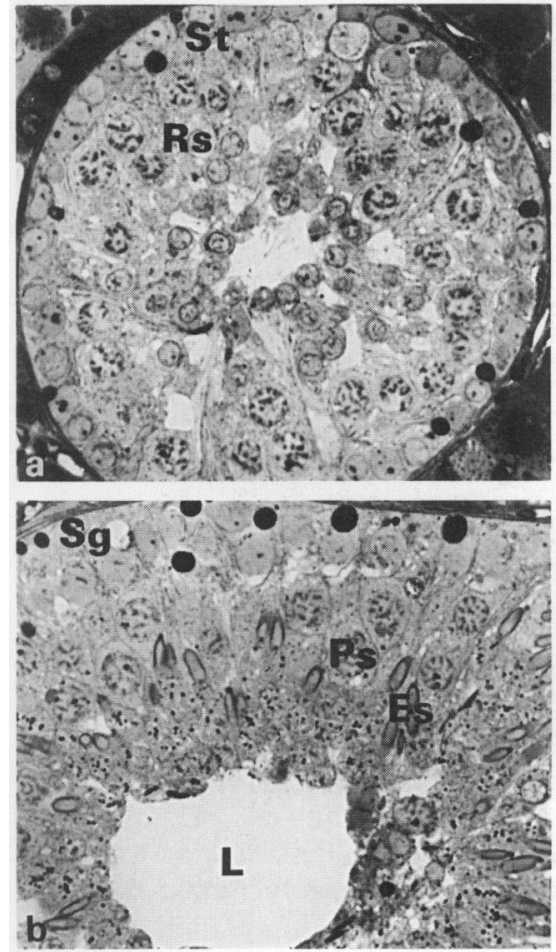
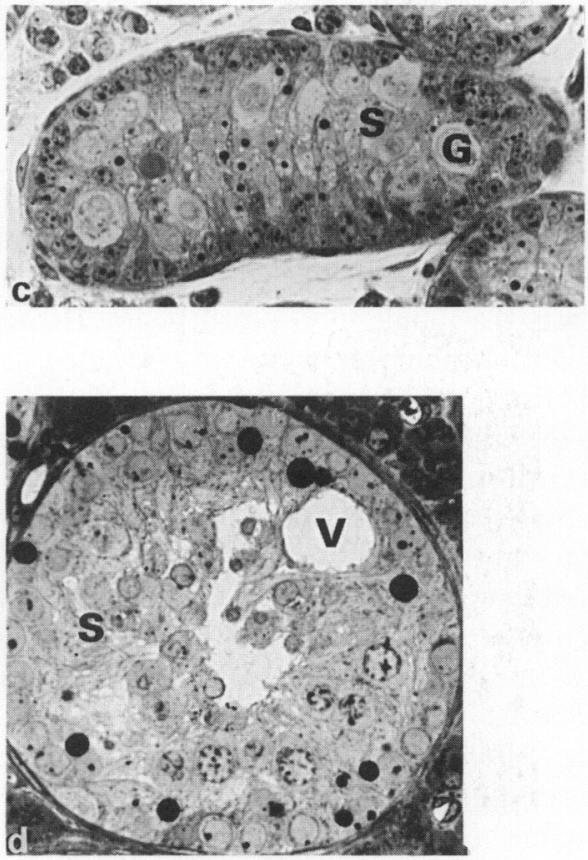

Fig. 6. Light micrographs of seminiferous tubules from Trial-1 intact boars (a) and boars hemicastrated on Day 10 (b) as well as for Trial-2 intact boars (c) and boars hemicastrated on Day 10 (d) at 122 days of age. Seminiferous tubules (St) contain Sertoli cells (S), gonocytes (G), spermatogonia $(\mathrm{Sg})$, primary spermatocytes (Ps), round spermatids (Rs), elongated spermatids (Es), lumen (L) and vacuoles (V). Spermatogenesis has progressed further in Trial-1 than in Trial -2 boars within each treatment. Staining $1 \%$ toluidine blue; $\times 325$.

between compensatory testicular development and testicular steroidogenesis. The fact that neonatal hemicastration of boars and other species does not influence plasma testosterone concentrations (Barnes et al., 1980b; Boockfor et al., 1983; Jenkins \& Waites et al., 1983; Waites et al., 1983; Kosco et al., 1987) indicates that intratesticular testosterone production is greater in GroupHC than in Group-I boars (Lindner \& Rowson, 1961; Moger et al., 1985). Compensatory increase in testicular weight, seminiferous tubule length and Sertoli cell numbers was drastically reduced in boars hemicastrated at 3-5 months of age in comparison to those hemicastrated at 1 or 2 months (Putra \& Blackshaw, 1985). Hormone profiles were not determined in the study of Putra \& Blackshaw (1985) but it may well be that hemicastration in 2-month-old boars was performed when testosterone secretion was at its lowest level. The 3-month-old and older boars appear to have been well into the pubertal testosterone secretory phase when hemicastration was performed, but the response of pituitary hormones is unknown. Growth hormone or FSH and testicular steroids may have a synergistic effect on compensatory proliferation of Sertoli cells, resulting in elongation of the seminiferous tubule in Group-HC boars, but the ability of the Sertoli cells to respond with proliferation might be greatly reduced when spermatogenesis begins.

Neonatal hemicastration of boars at 10 days of age did not influence the number or size of gonocytes but resulted in an earlier pubertal increase in mass of Sertoli cells, onset of spermatogenesis and seminiferous tubule luminal development when compared to Group-I boars. Likewise, Trial-1 but not Trial-2 Group-I boars exhibited such pubertal changes before the end of 
the study. Since during the first 80 days of life testicular mass (Kosco et al., 1987) as well as length and diameter of the seminiferous tubule were the same for both trials, and since plasma testosterone concentration was greater in Trial-1 than in Trial-2 boars (Kosco et al., 1987), the seminiferous tubule in Trial-1 boars was in all probability exposed to a higher intratesticular steroid concentration per unit of surface area during this time than was that in Trial-2 boars. Although plasma testosterone concentrations were similar for Group-HC and Group-I boars (Kosco et al., 1987), hemicastrated individuals have greater steroid production per testis than do intact individuals (Lindner \& Rowson, 1961; Moger et al., 1985). Since doubling of the length of the seminiferous tubule in Group-HC boars was not complete until 38 days of age, the tubule from 10 to 38 days of age in these boars may have been exposed to greater intratesticular steroid concentrations per unit than was the tubule in Group-I boars. Higher intratesticular steroid concentrations per unit of seminiferous tubule are therefore associated with earlier onset of spermatogenesis in boars in Trial 1 and Group HC.

In the bull earlier onset of spermatogenesis after neonatal hemicastration is preceded by accelerated transformation of mesenchymal cells into testosterone-secreting Leydig cells, probably facilitated by elevated FSH and/or GH secretion (Al-Haboby et al., 1988). In the present study these pituitary hormones were elevated in Group-HC boars but not in the Trial-2 boars. Although elevated testosterone is the apparent common denominator for Trial-1 boars and Group-HC boars (Kosco et al., 1987) exhibiting earlier onset of spermatogenesis, the underlying mechanism may involve one or more of the presumably paracrine intratesticular, regulatory factors (Tähkä, 1986; Papadopoulos et al., 1987).

The difference between trials in mass of Sertoli and spermatogenic cells of Group-HC boars coincides with the difference observed in plasma prolactin concentration noted previously for these same boars (Kosco et al., 1987). However, plasma concentrations of prolactin were related to the onset of spermatogenesis rather than as a result of hemicastration. The mechanism by which prolactin influences early pubertal Sertoli cell function and spermatogenesis, although unclear, appears to be by indirectly influencing the receptiveness of Leydig cells to LH stimulation and androgen secretion (Bohnet \& Friesen, 1976; Zipf et al., 1978; Stoud et al., 1985).

This is Scientific Journal Publication series no. 69,965 of the Minnesota Agricultural Experiment Station. We thank Dr Steven Fehrer for invaluable instruction given during the computer analysis of the data; Mrs Marion Wagner for technique instruction; and Ms Lynda Keck for typing the manuscript.

\section{References}

Al-Haboby, A., Crabo, B.G., Loseth, K.J., Lodhi, L.A. \& Kosco, M.S. (1984) Effect of unilateral castration in the prepubertal bull. Proc. I0th Int. Congr. Anim. Reprod. \& A. I., Urbana-Champaign, vol. 2, No. 264 ( 3 pages).

Al-Haboby, A.H., Loseth, K.J., Wheaton, J.E. \& Crabo, B.G. (1988) Neonatal hemiorchidectomy of bulls alters plasma growth hormone levels and advances onset of pubertal testosterone secretion. Dom. Anim. Endocr. 5, 61-69.

Barnes, M.A., Longenecker, J.V., Charter, R.C., Reisen, J.W. \& Woody, C.O. (1980a) Influence of unilateral castration and increased plane of nutrition on sexual development of Holstein bulls. I. Growth and sperm production. Theriogenology 14, 49-57.

Barnes, M.A., Longenecker, J.V., Reisen, J.W. \& Woody, C.O. (1980b) Influence of unilateral castration and increased plane of nutrition on sexual develop- ment of Holstein bulls. III. Endocrine responses. Theriogenology 14, 67-79.

Björkman, N. (1962) Low magnification electron microscopy in histological work. J. Ultrastruct. Res. 6, 343-348.

Bohnet, H.G. \& Friesen, H.G. (1976) Effect of prolactin and growth hormone on prolactin and $\mathrm{LH}$ receptors in the dwarf mouse. J. Reprod. Fert. 48, 307-3I1.

Boockfor, F.A., Barnes, M.A., Kazmer, G.W., Halman, R.D., Bierley, S.T. \& Dickey, J.F. (1983) Effects of unilateral castration and unilateral cryptorchidism of the Holstein bull on plasma gonadotropins, testosterone and testis anatomy. J. Anim. Sci. 56, 1376-1385.

Chevalier, M. (1979) Sertoli cell ultrastructure. II. Morphological effects of hypophysectomy in pubescent pigs. Annls Biol. Anim. Biochim. Biophys. 19, 583-596. 
Colenbrander, B., de Jong, F.H. \& Wensing, C.J.G. (1978) Changes in serum testosterone concentration in the male pig during development. J. Reprod. Fert. 53, $377-380$.

Courot, M. (1967) Endocrine control of the supporting and germ cells of the impubertal testis. J. Reprod. Fert., Suppl. 2, 89 95.

Cunningham, G.R., Tindall, D.J., Huckins, C. \& Means, A.R. (1978) Mechanism for the testicular hypertrophy which follows hemicastration. Endocrinology 201, 16-23.

Erickson, B.H., Murphree, R.L. \& Andrews, J.F. (1963) Effects of prenatal gamma irradiation on the germ cells of the male pig. Radiat. Res. 20, 640648 .

Fritz, I.B. (1978) Sites of action of androgens and follicle stimulating hormone on the cells of the seminiferous tubule. In Biochemical Action of Hormones, pp. 249 281. Ed. B. Lutwak. Academic Press, New York.

Herrera, J., Sosa, M., Ayala, F., Galina, C., Javrequi, P. \& Bermudez, J. (1983) Morphophysiological correlation of boar Leydig cell development during postnatal stage. Cornell Vet. 73, 67-75.

Hochereau de Reviers, M.T., Land, R.B., Perreau, C. \& Thompson, R. (1984) Effect of season of birth and of hemicastration on the histology of the testis of 6 month-old lambs. J. Reprod. Fert. 70, 157-163.

Jenkins, N. \& Waites, G.M.H. (1983) Effects of hemicastration at various ages and oestradiol-17 $\beta$ on plasma concentration of gonadotrophins and estrogens, testicular growth and interstitial cell response in prepubertal lambs. J. Reprod. Fert. 67, 325-334.

Kosco, M.S., Bolt, D.J., Wheaton, J.E., Loseth, K.J. \& Crabo, B.G. (1987) Endocrine responses in relation to compensatory testicular growth after neonatal hemicastration in boars. Biol. Reprod. 36, $1177-$ 1185.

Land, R.B. \& Carr, W.R. (1975) Testis growth and plasma LH concentration following hemicastration and its relation with female prolificacy in the sheep. $J$. Reprod. Fert. 45, 495-501.

Lindner, H.R. \& Rowson, L.E.A. (1961) Androgens and related compounds in spermatic vein blood of domestic animals. III. The effect of unilateral orchidectomy on the rate of androgen secretion by the remaining testis in the immature calf. $J$. Endocr. 23, $167-170$.

Lipschütz, A. (1922) The so-called compensatory hypertrophy of the testicle after unilateral castration. $J$. Physiol., Lond. 56, 451-458.

Means, A.R., Dedman, J.R., Tash, J.S., Tindall, D.J., van Sickle, M. \& Welsh, M.J. (1980) Regulation of the testis Sertoli cell by follicle stimulating hormone. Ann. Rev. Physiol. 42, 59-64.

Moger, W.H., Anakwe, O.O. \& Bapat, B.V. (1985) Compensatory androgen secretion following hemicastration: influence of age and adrenergic antagonists. Biol. Reprod. 32 (Suppl. 1), 84, abstr.

Orth, J., Higginbotham, C. \& Salisbury, R. (1984) Hemicastration causes and testosterone prevents enhanced uptake of $\left[{ }^{3} \mathrm{H}\right]$ thymidine by Sertoli cells in testes of immature rats. Biol. Reprod. 30, 263-270.
Ott, K.M., Mannen, K.A., Dinger, J.E., Hoagland, T.A., Woody, C.O. \& Riesen, J.W. (1984) Effects of unilateral castration on the physiological and morphological characteristics of stallion testes. J. Anim. Sci. 59 (Suppl. 1.), Abstr. 512.

Papadopoulos, V., Kamtchouing, P., Drosdowsky, M.A., Hochereau de Reviers, M.T. \& Carreau, S. (1987) Adult rat Sertoli cells secrete a factor or factors which modulate Leydig cell function. J. Endocr. 114, 459-467.

Putra, D.K. \& Blackshaw, A.W. (1985) Quantitative studies of compensatory testicular hypertrophy following unilateral castration in the boar. Aust. J. biol. Sci. 38, 429-434.

SAS Institute Inc. (1982, ed) SAS Users Guide Basics. Cary, NC.

Steinberger, A. \& Steinberger, E. (1977) The Sertoli cells. In The Testis, vol. 4, pp. 371-399. Eds A. D. Johnson \& W. R. Gomes. Academic Press, New York.

Stoud, C.M., Moden, P.F. \& Whitsett, J.M. (1985) Bromoergocryptine decreases serum prolactin and delays sexual maturation in male golden hamsters. Biol. Reprod. 32, 1191-1199.

Sundby, A., Andresen, O. \& Standal, N. (1981) Effect of hemicastration on the level of testicular steroids and growth in bulls and boars. Theriogenology 16, 249-257.

Swierstra, E. (1976) Testicular development and establishment of spermatogenesis in the boar. Proc. 4th Int. Cong. Pig Vet. Soc., Ames, Abstr. D.10.

Tähkä, K.M. (1986) Current aspects of Leydig cell function and its regulation. J. Reprod. Fert. 78, $367-380$.

Tran, D., Meusy-Dessolle, N. \& Josso, N. (1981) Waning of anti-mullerian activity: an early sign of Sertoli maturation in the developing pig. Biol. Reprod. 24, 923-931.

Trump, B., Smuckler, E.A. \& Benditt, E.A. (1961) A method for staining epoxy sections for light microscopy. J. Ultrastruct. Res. 5, 343-348.

van Straaten, H.W.M. \& Wensing, C.J.G. (1977) Histomorphometric aspects of testicular morphogenesis in the pig. Biol. Reprod. 17, 467-472.

Voglmayer, J.K. \& Mattner, P.E. (1968) Compensatory hypertrophy in the remaining testis following unilateral orchidectomy in the adult ram. J. Reprod. Fert. 17, 179-181.

Waites, G.M.H., Wenstrom, J.C., Crabo, B.G. \& Hamilton, D.W. (1983) Rapid compensatory hypertrophy of the lamb testis after neonatal hemiorchidectomy: endocrine and light microscopical morphometric analysis. Endocrinology 112, 2159-2167.

Weibel, E. (1979) Stereological Methods. Academic Press, New York.

Zipf, W.B., Payne, A.H. \& Kelch, R.P. (1978) Prolactin, growth hormone and luteinizing hormone in the maintenance of testicular luteinizing hormone receptors. Endocrinology 103, 595-600.

Received 5 August 1988 